\title{
Mineralogical Characterization of Slags from the Oiola Site (Biscay, Spain) to Assess the Development in Bloomery Iron Smelting Technology from the Roman Period to the Middle Ages
}

\author{
Haizea Portillo-Blanco ${ }^{1}$, Maria Cruz Zuluaga ${ }^{1, *} \mathbb{0}$, Luis Angel Ortega ${ }^{1}(\mathbb{D}$, \\ Ainhoa Alonso-Olazabal ${ }^{1}$, Juan José Cepeda-Ocampo ${ }^{2} \mathbb{D}$ and Ana Martínez Salcedo ${ }^{3}$ \\ 1 Department of Mineralogy and Petrology, Faculty of Science and Technology, University of the Basque \\ Country, P.O. Box 644, E-48080 Bilbao, Spain; haizea.portillo@ehu.eus (H.P.-B.); luis.ortega@ehu.eus (L.A.O.); \\ ainhoa.alonso@ehu.eus (A.A.-O.) \\ 2 Department of Historical Sciences, Faculty of Philosophy and Letters, University of Cantabria, \\ E-39005 Santander, Spain; juan.cepeda@unican.es \\ 3 ARKEON, 6, Plaza Julio Lazurtegui, 4, E-48014 Bilbao, Spain; arkeon@euskalnet.net \\ * Correspondence: mcruz.zuluaga@ehu.eus
}

Received: 10 January 2020; Accepted: 1 April 2020; Published: 3 April 2020

\begin{abstract}
The Oiola archeological site, located in the mining complex of La Arboleda (Biscay, North Spain) was an important iron smelting center from the Roman Period to the Middle Ages and even in more current times (19th-20th centuries). Tap-slags and some plano-convex slags were identified as smelting slags. Samples were analyzed by optical microscopy, X-ray powder diffraction, scanning electron microscopy coupled with electron-dispersive spectroscopy and Raman microspectroscopy to perform a mineralogical and textural characterization. Additionally, thermogravimetric and thermodiffraction analyses were carried out to determine furnace operating temperatures. The mineral assemblage reflects furnace temperatures and cooling rates and the addition of quartz as the main flux to decrease the melting temperature of the iron ore. The comparison of slags from the Roman Period and the Middle Age reveals changes in the pyrometallurgical process through time.
\end{abstract}

Keywords: smelting slags; archaeological slags; furnace operating conditions; Roman Period; Middle Age; North Spain

\section{Introduction}

In ancient times, from the Iron Age to the appearance of cast iron and blast furnaces in the Middle Ages (10th century BC-20th century AD) iron was obtained by the direct solid-phase reduction method, also called "bloomery" method. In the bloomery, the iron oxides from the ore are processed in one step in a furnace with carbon-based fuel where charcoal acts as reducing agent reaching temperatures of about $1200{ }^{\circ} \mathrm{C}$. [1-6]. Inside the furnace, carbon monoxide (CO) gas emanating from the charcoal reacts with iron oxide $(\mathrm{FeO})$ in the ore to form solid iron particles and carbon dioxide $\left(\mathrm{CO}_{2}\right)$ gas [7]. Additionally, to reach the high temperatures needed, bellows were used to blow air into the furnace through one or more blowing holes in the furnace sides. Sometimes ceramic tubes (known as tuyères) were inserted into the furnace to inject air inside [7]. Fluxes can also be added deliberately to promote greater iron efficiency and lower melting temperatures [6]. The flux materials usually consist of limestones, quartz rich sands and sandstones $[2,7,8]$.

The metallic product, called bloom, is a heterogeneous spongy mass, more or less consolidated and with a large number of pores. The reduction of the iron starts at temperatures of around $800{ }^{\circ} \mathrm{C}$ but 
the metal never reaches melting temperature (as high as $1540{ }^{\circ} \mathrm{C}$ ) and remains a pasty mass $[2,5,9-12]$. The other substances present in the load inside the furnace, such as silica, alumina and unreduced iron oxides, are removed as a liquid phase and separated by flowing away from the metal as iron smelting slag [2,6]. Some of these impurities can also be driven off as a gas, alloy with the iron or even stay inside the furnace [13]. The solid iron bloom, much denser than the slag, does not sink to the base of the furnace and attaches to the furnace wall just below the emplacement of clay nozzles or tuyères [14].

The slags are essentially the main by-product of the iron production process. The composition of smelting slags depends on the furnace operation conditions (design, air supply mechanism), the raw material used (ore, charcoal, furnace lining) and the potential use of fluxes [10,15-17]. Besides, slags might contain other constituents formed by reactions with impurities in the ore or with molten material from the furnace, such as the tuyères ceramic $[10,16,17]$. Therefore, smelting slags have a composition near that of fayalite $\left(\mathrm{Fe}_{2} \mathrm{SiO}_{4}\right)$ and are formed by the reaction of the iron oxide and silica from the added sand at high temperatures $\left(1200{ }^{\circ} \mathrm{C}\right)$ resulting in a molten ferrosilicate slag. These slags contain both fayalite crystals and residual glass of similar composition and sometimes with fine crystals of fayalite. When iron oxide is in excess, dendrites of wuestite and/or magnetite also precipitate. Besides silicates and oxides, iron slags almost invariably contain droplets of metallic iron $[18,19]$. The formation of slag reduces the amount of $\mathrm{FeO}$ available for reduction and provides a fluid medium in which metallic particles can be transported fused into larger masses, and protected from re-oxidation [7].

According to textural, mineralogical and chemical features, iron-smelting slags can be further classified into different groups. The most characteristic type of slag from the bloomery processes is tap-slag. Tap-slags are usually very heavy, compact with absence of blowholes and completely melted homogeneous pieces. They also have a shiny black surface with cord-like flows or flat slab structures when tapped and cooled outside the furnace and flat base. Minor gas bubbles can be found in their dark-grey fractures $[19,20]$. These morphological features are usual in the "tapping furnaces" that have a hole in the furnace wall at ground level used to run out the slag during the smelting.

In other cases, when the furnace is situated in an excavated pit, the slags are trapped at the base and form a cylindrical shape; this is called cinder-slag. The morphology of cinder-slag is varied and randomly shaped but usually are large, strongly indented, sponge-like and full of blowholes with a fritted cindery appearance [2,20]. Also are highly siliceous and sometimes calcareous and charcoal inclusions can appear $[1,2,20,21]$. Transition slags combining the properties of both groups can also exist. This type of slag is completely melted, compact and with a morphology similar to the cinder-slags [20].

The texture of the slag, vitreous or crystallized, is related to the cooling conditions [2] while the slag mineralogy depends mainly on chemical constraints imposed by raw and flux materials on the furnace temperature, redox conditions and reaction speed [1,6,7]. All the materials involved in smelting even from the same source area are texturally heterogeneous and compositionally variable conditioning also the composition of slag [17].

The air supply mechanism and the fuel to ore ratio are factors to provide the temperature and a reducing atmosphere required in the furnace. Both conditions are necessary to reduce the iron minerals in the ore into a single mass. Besides slags must remain fluid with the adequate low viscosity to separate from the bloom at the time they are produced $[7,17]$. Conversely, if the conditions within the furnace are not reducing enough, an iron-rich fluid slag is formed and so no metal is produced [21]. Therefore, during the production of metallic iron, a considerable amount of ferric oxide is wasted leading to slag formation and bloomery smelting was fairly inefficient process [15].

Slags constitute the largest available and most accessible materials for research into ancient iron production technologies. When iron smelting furnace remains or other archaeological evidence of mineral processing activity is not found, the study of textural and mineralogical features of slags can provide information about bloomery smelting techniques and the furnace conditions.

The aim of this work is to determine compositional and textural similarities or differences of Roman and Middle Age slags from the archaeological site of Oiola (Biscay, Spain) in order to establish the 
development of iron-making processes and technologies through time. As mineralogical composition and textural features of slags are closely related to the materials used during smelting, factors such as the combination of materials used, furnace design, air supply mechanism, fuel type or operating procedures and conditions can be determined.

\section{Oiola Site}

The archaeological site of Oiola is located between the municipalities of Trapagarán and Galdames (Biscay) (Figure 1a). The area is within the mining complex of La Arboleda exploited from Roman times until the 20th century. The metallurgical workshop of Oiola is one of the archaeological sites belonging to the Roman and medieval periods in the North Iberian Peninsula. The site consisted of a set of organized structures corresponding to the iron reduction or smelting process from the Late Roman Period (4th century AD) to the Middle Ages (from 10th to 13th centuries) [22].

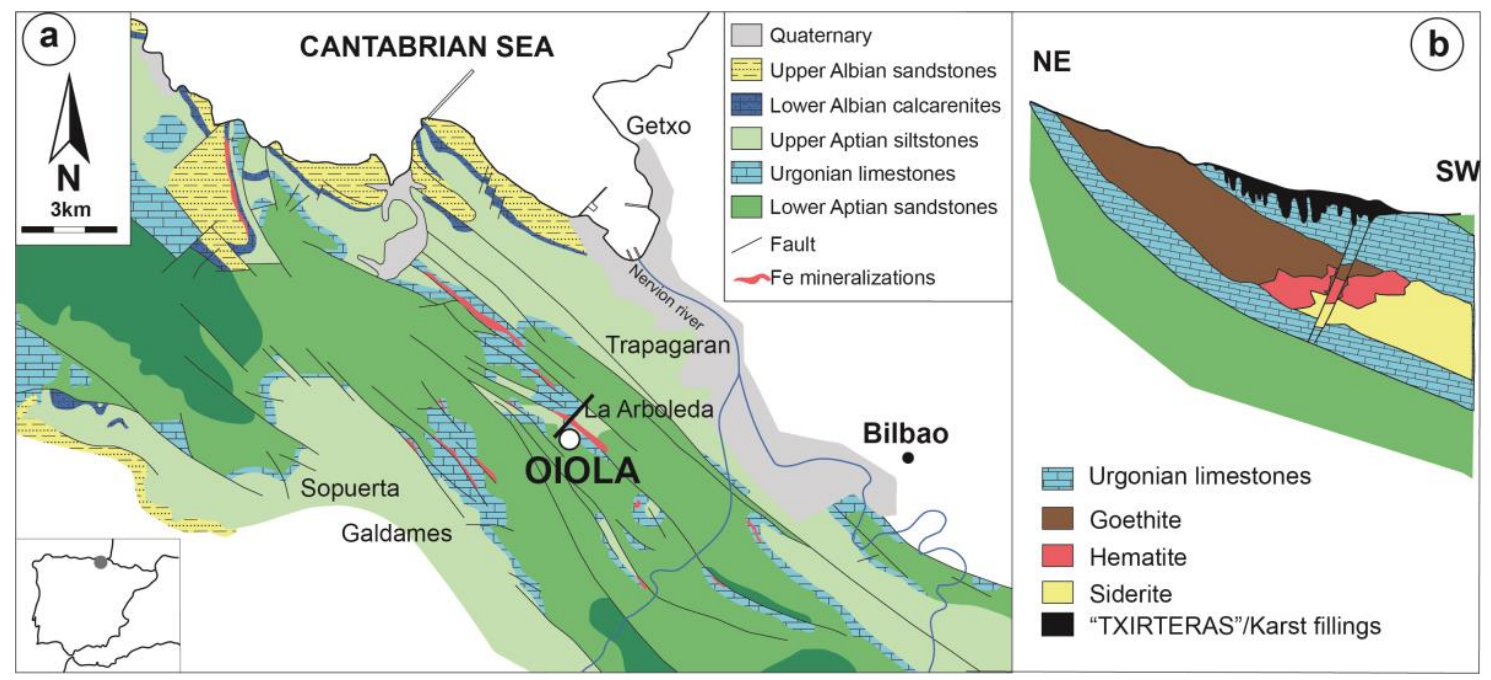

Figure 1. (a) Geographical location and geological setting of Oiola archaeological site; (b) scheme of the type of mineralization the iron oxyhydroxides (modified from [23]).

During the archaeological excavations carried out between 1989 and 1992, in several areas large amounts of slags were found indicating intense iron production activity. The oldest archaeological finds consist of smelting slags from the Oiola II area dated in the Late Roman Empire (4th century AD). Nowadays Oiola II is located $4 \mathrm{~m}$ below the average level of the Oiola reservoir. On the banks of the river El Cuadro (Trapagaran, Biscay) terraces formed by slags, charcoal and burnt earth appeared indicating an intense occupation of the space used in the transformation of the mineral into metal. Three mounds with slag and charcoal remains are visible on the terraces and since no furnace structure remains were found, it is supposed these mounds could correspond to remains of iron reduction furnaces [22]. The Oiola IV area is dated in the Middle Ages and is located $39 \mathrm{~m}$ above Oiola II. The site corresponds to a large slag heap in the gorge of El Cuadro stream (Trapagaran, Bizcay) and is located close to the Oiola reservoir. Moreover, two types of structures were identified, one corresponding to reduction furnaces the Structure 1, and perhaps the Structure 4 and a second type possibly corresponding to forging furnace the Structure 3 [22].

During Roman times and the Middle Ages (until the 19th century) iron ores used in Oiola for iron reduction were mainly composed of goethite, hematite and limonite [23]. This limonite is composed of amorphous and crystalline iron-hydroxides and iron-oxides in varying compositions, mainly yellow-brownish goethite $(\alpha-\mathrm{FeO}(\mathrm{OH}))$ formed under oxidizing conditions and in association with minor amount of hematite $\left(\alpha-\mathrm{Fe}_{2} \mathrm{O}_{3}\right)$. This type of ore constituted by this mineral assemblage is called "bog iron ore" or "bog ore" [24,25]. 
In general, bog iron ores are organized by a ferric upper zone generated under oxidizing conditions and a ferrous lower zone generated under reducing conditions [26-28]. The composition of the ore and the prevailing iron-oxides and iron-hydroxide phases depend on the composition of the parent geological materials, the hydrology of the area and, the composition and fluxes of groundwater $[27,28]$.

The Oiola site and La Arboleda mining complex are located on Lower Cretaceous materials, mainly of Aptian and Albian ages. The Aptian-Albian series is represented by Urgonian and Supra-Urgonian limestones [29] (Figure 1a). Urgonian limestones were formed when the opening of the Bay of Biscay (Rift type) took place. Thermal solutions transported iron through higher porosity materials and fractures leading to the replacement of limestones by iron carbonates (siderite). Subsequent uplifting and erosion favor siderite alteration and oxidation in supergenic conditions, forming hematite and goethite iron-oxides and iron-hydroxides as secondary mineralization [30].

Goethite is the main mineral in surface areas with abundant water circulation occurring with botryoidal textures, while hematite is the main mineral in more protected areas. Iron ore eroded materials can be trapped in karst cavities in limestone and these fills consist of goethite, hematite, quartz and clays forming gossans or iron caps, that locally are named "txirteras" [23,30] (Figure 1b).

\section{Materials and Methods}

\subsection{Sampling}

The studied samples correspond to 31 iron smelting slags stored in the Archaeological Museum (Bilbao, Spain) (Table 1). Ten samples correspond to Roman slags from the Oiola II area and the remaining 21 slags to the Oiola IV area dated in the Middle Ages. The slag samples are mainly specimens several centimeters in size $(8 \times 5 \times 4 \mathrm{~cm})$ and were hardly weathered on the surface. Samples are currently stored in the Archaeological Museum (Bilbao, Spain) and the details of the excavation are described in [22]. Each slag was divided in two parts: one for textural observations and chemical analyses by means of a polished thin section while the other was crushed and pulverized for mineral studies. Additionally an ore sample and a mixture of ore and quartz sample were analyzed in order to establish smelting conditions.

\subsection{Optical Microscopy}

The mineralogical and textural characterization of slags were observed in polished thin sections by light polarized microscopy using a petrographic polarizing Eclipse LV100POL microscope (Nikon, Tokyo, Japan) equipped with a DS F-11digital camera (Olympus, Tokyo, Japan). The microscope observations were performed using both transmitted and reflected light modes. Optical microscopy characterizations were carried out in the Mineralogy and Petrology Department in the Basque Country University (UPV/EHU).

\subsection{X-ray Powder Diffraction}

The mineralogical assemblage of slags was determined by a Phillips X'Pert diffractometer (Malven PANalitical, Almelo, The Netherlands) equipped with monochromatic $\mathrm{Cu}-\mathrm{k} \alpha_{1} \mathrm{X}$-radiation operating at $40 \mathrm{kV}$ and $20 \mathrm{~mA}$. Data collection on the powder samples were performed by a continuous scan in the range $5^{\circ}$ to $70^{\circ}$ theta and at $0.02^{\circ}$ per second 2 theta acquisition rate. Before XRD (X-ray diffraction) analysis, samples were ground up using an agate mortar of a Pulverisette Vibratory Micro Mill (Fritsch, Einersheim, Germany). Then randomly oriented powder mount was poured into the sample holder with an automatic 15-position charger. The X'Pert HighScore Plus 3.0 software (Malven PANalitical, Malven, UK) were used to phase identification and semi-quantitative calculation using experimental ICCDD and ICSD diffraction database.

Powder X-ray Thermodiffraction (TDX) was performed to observe phase transitions in order to simulate the smelting process. XRD data were collected with a D8 Advance diffractometer (Bruker, Billerica, MA, USA) operating at $30 \mathrm{kV}$ and $20 \mathrm{~mA}$, equipped with a Cu tube $(\lambda=1.5418 \AA$ ) , a Vantec-1 
PSD detector, and a HTK2000 high-temperature furnace (Anton Parr, Graz, Austria). The powder patterns were recorded in 2 steps of $0.033^{\circ}$ in the $20^{\circ}-70^{\circ}$ 2Theta range, counting for $3 \mathrm{~s}$ per step (total time for each temperature 1:24 h). Data sets were recorded from $30{ }^{\circ} \mathrm{C}$ to $1205^{\circ} \mathrm{C}$ each $25{ }^{\circ} \mathrm{C}$ at $0.166^{\circ} \mathrm{C} \mathrm{s}^{-1}$ heating rate. International Centre for Diffraction Data as the Powder Diffraction File (PDF) integrated in the software of the instrumentation was used for phase identification. XRD analyses were performed in the Materials and Surface Unit of the Advanced Research Facilities (SGIker) in the Basque Country University (UPV/EHU).

\subsection{Scanning Electron Microscopy with Energy Dispersive X-ray Spectroscopy}

Mineralogical and textural characterization was performed using a JEOL JSM 6400 scanning electron microscope (SEM) operating with an INCA EDX detector X-sight Series Si (Li) pentaFET Oxford. Microtextural observations and elemental analysis were performed on polished thin sections and to eliminate charging effects samples were carbon-coated. Qualitative microanalysis was carried out using the ZAF method, which is based on the correction of the matrix effect in multi-elemental analysis that takes place in the simultaneous determination of the concentration of each element present in a multi-element material. This method provides X-ray intensity correction, absorption correction, and the fluorescence correction produced by the atomic number effect of each element, by the composition and depth of electron penetration, and by the secondary fluorescence respectively. The counting time for punctual analyses was $60 \mathrm{~s}$. Concentrations were calculated by stoichiometry from elements generated by ZAF software. SEM-EDX analyses were performed in the Materials and Surface Unit of the Advanced Research Facilities (SGIker) in the Basque Country University (UPV/EHU).

\subsection{Raman Microspectroscopy}

Raman analyses were performed with a Renishaw inVia Raman spectrometer and two lasers coupled with a Leica DMLM microscope using three objectives $(5 \times, 20 \times$, and $50 \times)$, resulting in a spot of 1-2 $\mu \mathrm{m}$. The excitation wavelengths of the laser are $514 \mathrm{~nm}$ (green) and $785 \mathrm{~nm}$ (NIR) allowing analysis using two different sources to enable the avoidance of possible fluoresce-based phenomena. The lasers have nominal power at the source of $50 \mathrm{~mW}$ and $400 \mathrm{~mW}$, and the maximum powers at the sample are $20 \mathrm{~mW}$ and $500 \mathrm{~mW}$, respectively. Raman spectra were recorded between $1000-100 \mathrm{~cm}^{-1}$ with a $1 \mathrm{~cm}^{-1}$ resolution and a very reasonable signal-noise ratio. Raman spectra were collected with Renishaw's WiRE'T 2.0 software and the peak search algorithm embedded in the software was used to determine the wavenumber for each Raman mode. Raman microspectroscopy analyses were performed in the Raman-LASPEA laboratory of the Advanced Research Facilities (SGIker) in the Basque Country University (UPV/EHU).

\subsection{Thermo-Gravimetric Analysis (TGA)}

Thermogravimetric analysis (TGA) was performed in a TA SDT 2960 TG-DSC simultaneous instrument (TA Instruments, New Castle, DE, USA). Pt crucibles containing 5 to $7 \mathrm{mg}$ of sample were heated at $2{ }^{\circ} \mathrm{C} \mathrm{min}^{-1}$ from room temperature to $1200{ }^{\circ} \mathrm{C}$. The thermogravimetry technique allows to characterize solid state reactions of sample mineral phases as the temperature increases by means of changes in the mass of the sample. Thus, TGA analysis allows to estimate the temperature conditions during the process of iron reduction in ancient bloomery furnaces. Therefore, in order to reproduce the furnace conditions, both inert (argon) and oxidizing atmospheres were used in TGA analyses. TGA analyses were carried out in the Inorganic Chemistry Department in the Basque Country University (UPV/EHU).

\section{Results and Discussion}

According to macroscopic features, as surface morphology, density and colour, most of samples correspond to tap-slags in both Roman and Medieval periods. Tap-slags show a ropey structure and basal shapes resulting from shape of tapping channel or the slag cooling bed and, are dense. Most of 
these slags have intact morphology but not the surface color because not only show grey to black colors but also reddish colored surfaces due to the secondary products caused by surface oxidation. In cut section tap-slags show variable amount of vesicles (Figure 2a-e). Furnace-bottom slags also occur in minor amounts in the Medieval period, whereas cinder slags occasionally occur in the Roman period. Only two samples are classified as furnace-bottom slags showing little morphological differences. Bottom-slag of Group 2 shows plano-convex shape and slag of Group 3 shows plano-bottom shape. Both slags show an irregular upper surface with the external morphology and color altered to reddish dull color and bright grey in cut section (Figure 2c). However smelting furnace bottom slags can easily be confused with smithing hearth slags since morphologically can be identical. Thus, according to macroscopic features is difficult to differentiate whether bottom furnace slags are from smithing or smelting [3,31]. The cinder-slag is hemicylindrical elongated shaped with the external morphology completely changed and sponge-like structure with clay or stone and charcoal fragments attached and lower density. Due to surface oxidation shows reddish dull color but in cut-section shows bright grey color and large amount of vesicles (Figure 2e).

Table 1. Studied smelting slags indicating the age of samples and macroscopic features.

\begin{tabular}{|c|c|c|c|c|c|c|}
\hline & Site & Period & Age & Sample & Slag Type & Slag Features \\
\hline 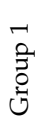 & OIOLA IV & $\begin{array}{l}\text { Middle } \\
\text { Ages }\end{array}$ & $\begin{array}{l}\text { 10th to } 13 \text { th } \\
\text { centuries AD }\end{array}$ & $\begin{array}{c}\text { OI-26-2 } \\
\text { OI-32 } \\
\text { OI-33-44E } \\
\text { OI-33-45E }\end{array}$ & Tap-slags & $\begin{array}{l}\text { Strong magnetism and } \\
\text { porosity }\end{array}$ \\
\hline 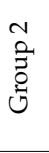 & OIOLA IV & $\begin{array}{l}\text { Middle } \\
\text { Ages }\end{array}$ & $\begin{array}{l}\text { 10th to } 13 \text { th } \\
\text { centuries AD }\end{array}$ & $\begin{array}{c}\text { OI-18 } \\
\text { OI-22-13E } \\
\text { OI-22-18E } \\
\text { OI-22-51E }\end{array}$ & Plano-convex & $\begin{array}{l}\text { Moderate magnetism and } \\
\text { porosity }\end{array}$ \\
\hline 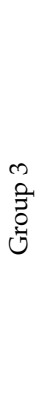 & OIOLA IV & $\begin{array}{l}\text { Middle } \\
\text { Ages }\end{array}$ & $\begin{array}{l}\text { 10th to } 13 \text { th } \\
\text { centuries AD }\end{array}$ & $\begin{array}{c}\text { OI-19 } \\
\text { OI-20 } \\
\text { OI-21 } \\
\text { OI-22-16E } \\
\text { OI-22-23E } \\
\text { OI-23-22E } \\
\text { OI-25-43E } \\
\text { OI-25-50E } \\
\text { OI-26-1 } \\
\text { OI-27 } \\
\text { OI-28 } \\
\text { OI-31 } \\
\text { OI-27-57E }\end{array}$ & $\begin{array}{c}\text { Tap-slags } \\
\text { Plano-convex }\end{array}$ & $\begin{array}{c}\text { Low/absence of } \\
\text { magnetism and low } \\
\text { porosity }\end{array}$ \\
\hline 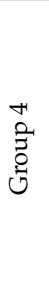 & OIOLA II & $\begin{array}{l}\text { Late Roman } \\
\text { Period }\end{array}$ & 4th century AD & $\begin{array}{l}\text { OI-II-02 } \\
\text { OI-II-03 } \\
\text { OI-II-04 } \\
\text { OI-II-05 } \\
\text { OI-II-06 } \\
\text { OI-II-07 } \\
\text { OI-II-08 } \\
\text { OI-II-09 } \\
\text { OI-II-10 }\end{array}$ & Tap-slags & $\begin{array}{l}\text { Strong magnetismand } \\
\text { low porosity }\end{array}$ \\
\hline 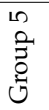 & OIOLA II & $\begin{array}{l}\text { Late Roman } \\
\text { Period }\end{array}$ & 4th century AD & OI-II-12 & Cinder slags & \\
\hline
\end{tabular}

Samples are classified according to pore amount and grade of magnetism (Table 1). Samples corresponding to Oiola IV (Middle Ages) are classified in three groups while Roman slags from Oiola II form two groups. Group 1 includes Middle Ages tap-slags displaying strong magnetism and high porosity (Figure 2a). Group 2 include both plano-convex slag and tap-slags of Middle Ages showing a medium degree of magnetism and porosity (Figure 2b). Group 3 include both plano-convex slag and tap-slags of Middle Ages showing weak/absence of magnetism and low porosity (Figure 2c). Group 4 corresponding to Roman tap-slags displays strong magnetism but low porosity (Figure 2d) whereas Group 5 corresponding to Roman cinder slag shows strong magnetism and high 
porosity (Figure 2e). Considering plano-convex smithing slags are usually magnetic and sometimes strongly magnetic [3,31] the moderate magnetism of OI-18 slag and the absence of magnetism of OI-27-57E slag point out these two slags are more of smelting than smithing, although it cannot be discard the OI-18 slag could correspond to smithing process.

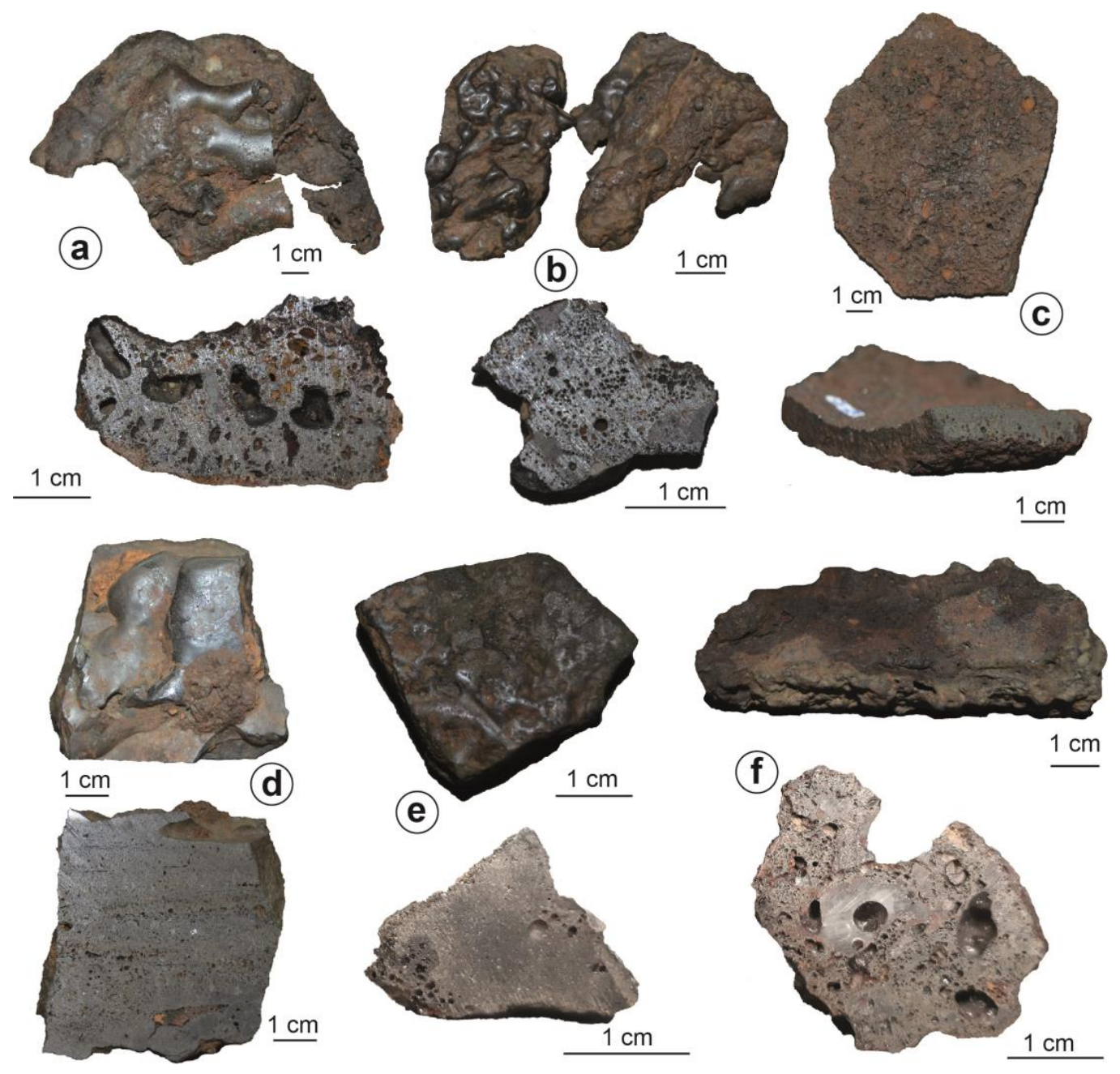

Figure 2. Photographs of representative samples of slags studied: (a) Group 1 very porous medieval slags, (b) Group 2 moderately porous medieval tap-slag, (c) Group 2 moderately porous medieval plano-convex slag. (d) Group 3 low porous medieval slag, (e) Group 4 low porous Roman slag. (f) Group 5 Roman cinder slag.

The microscopic analyses show all slags are formed mainly by olivine and wuestite and in some samples quartz is also abundant but mainly appearing on the external surface of the slags. Considering the macroscopic grouping, each slag group shows the following specific textural and mineralogical characteristics. Slag in Group 1 contains massive olivine surrounded by smaller skeletal olivine and dendritic wuestite minerals and very scarce vitreous matrix. Occasionally some small particles are present corresponding to metallic iron (samples OI-32). In reflected light mode, magnetite can also be distinguished showing euhedral crystals and sometimes cruciform-skeletal crystals [32] (Figure 3a). Textural features and the lighter bright grey color of magnetite discriminate reasonably well from wuestite by reflected light [33]. Sand fragments are observed on the external surface of the slags. Besides in the porous surfaces no crystalized minerals occur in a botryoidal structure. Slags in Group 2 are characterized by skeletal olivine and dendritic wuestite although some massive olivines are present. Wuestite appears embedded and intergrown within the olivines (Figure 3b). Similar to 
Group 1, quartz and botryoidal structures are also present (Figure 3c). Slags in Group 3 showing weak magnetism are characterized by the presence of some white lines evidencing a layered structure. These white lines are thin skins indicating the limit of individual slag flows coming out of the furnace (Figure 3d).

Elongated olivine crystallizes perpendicular to the white skins indicating the lower flow was already cooled before the following flow overlapped. This structure is similar to that formed in geological lava flows and is known as spinifex texture [34]. White lines in smelting slags are explained as thin skins of iron oxide formed when the surface of the slag flow oxidizes in contact with air [34,35].
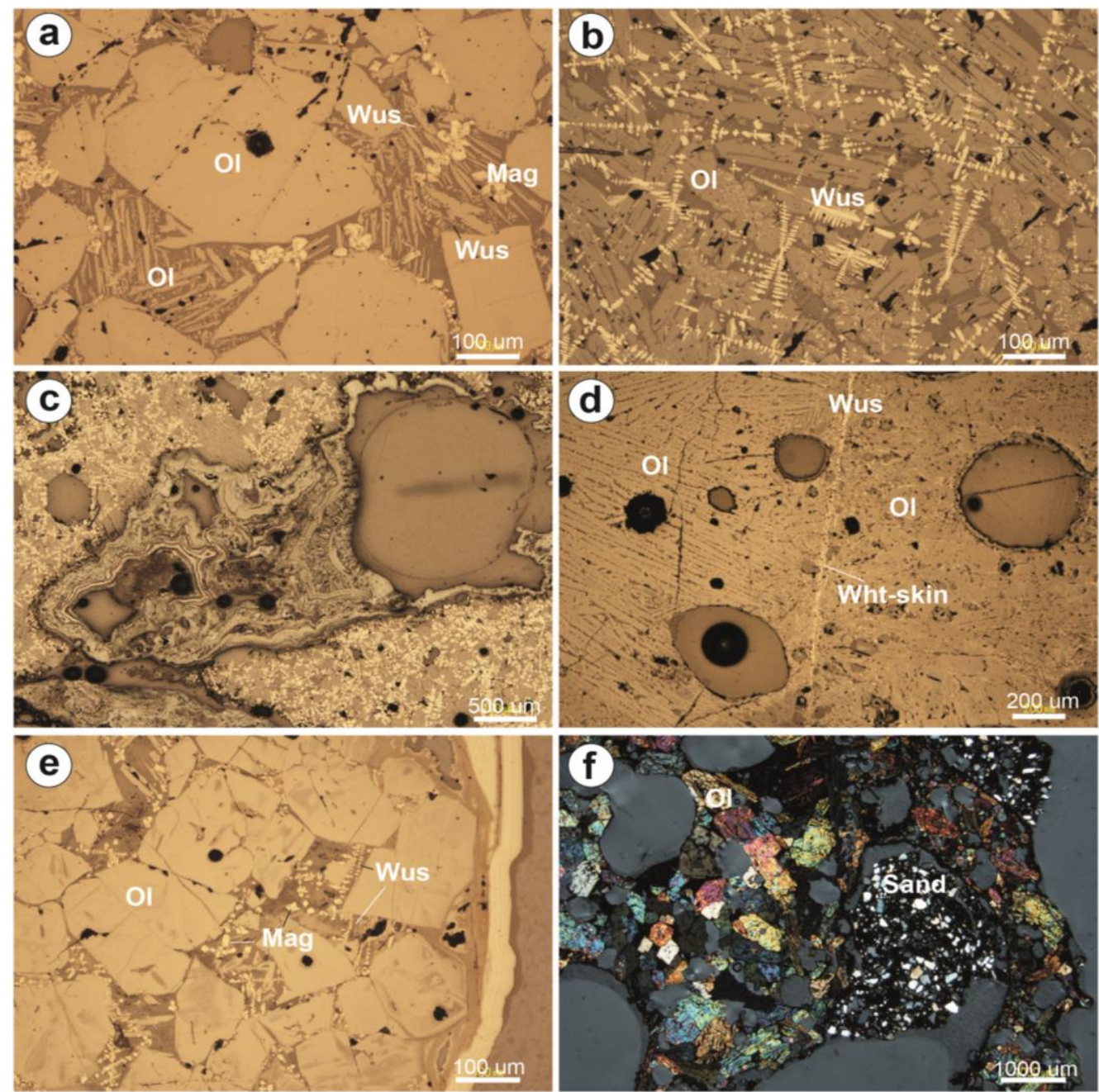

Figure 3. Photomicrographs showing microtextures of slags. (a) Massive and skeletal olivines and cruciform-skeletal crystals of magnetite in Medieval Group 1. (b) Skeletal olivines and dendritic wuestite intergrowing within olivines in Group 2. (c) Dendritic wuestite and botryoidal structure surrounding a pore. (d) white lines indicative of various flows in Group 3. (e) Massive olivines and cruciform-skeletal crystals of magnetite in Roman Group 4. (f) Massive olivine and sandstone fragment in Roman cinder-slag. $(\mathbf{a}-\mathbf{e})$ in reflected light mode and (f) in transmitted light in cross-polarized light mode. Abbreviations after [36]: Ol: Olivine, Wus: Wuestite, Mag: Magnetite, Wht-skin: white skin.

Within the Roman slags, samples in Group 4 show mainly massive olivine and low amount or absence of wuestite. Some cruciform magnetite crystals appear among olivine crystals also in botryoidal features on the external surface of the slags (Figure 3e). Occasionally sub-rounded small white particles are present corresponding to metallic iron. Slags in Group 5 also show massive olivine and scarcity or absence of wuestite but differ in the abundant sand fragments on the external surface of the slags 
(Figure 3f). Textually, Roman slags are similar to Group 1 of Medieval slags and are characterized by massive olivines. However, the Roman slags display lesser amount of wuestite than the Medieval slags.

Phase assemblages identified by X-ray powder diffraction of all the analyzed slags are summarized in Table 2. The determined mineralogy is in accordance with the petrographic observations. Samples from Oiola IV (Middle Ages) are mainly constituted by olivine and wuestite. Magnetite and quartz are also abundant in slags in Group 1 and Group 2 whereas in Group 3 slags magnetite is practically absent and quartz is less abundant or even absent. The presence or absence of magnetite is in accordance with the slag magnetism. Roman slags from Oiola II are mainly constituted by olivine and magnetite whereas wuestite and quartz are detected in lower amounts.

Table 2. XRD mineralogical composition of studied samples. Semiquantative values in percentage (\%).

\begin{tabular}{|c|c|c|c|c|c|c|}
\hline \multirow[t]{2}{*}{ Sample } & \multirow[t]{2}{*}{ Period } & \multicolumn{4}{|c|}{ Mineralogy } & \multirow{2}{*}{ Slag Group } \\
\hline & & Quartz & Magnetite & Olivine & Wuestite & \\
\hline OI-26-2 & \multirow{21}{*}{ 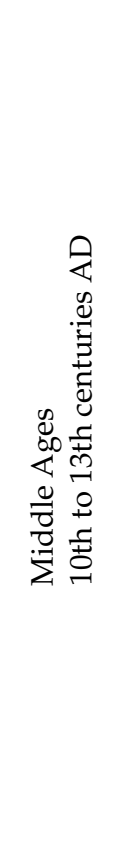 } & 15 & 20 & 40 & 26 & \multirow{4}{*}{ 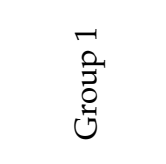 } \\
\hline OI-32 & & 38 & 15 & 32 & 15 & \\
\hline OI-33-44E & & 30 & 17 & 27 & 26 & \\
\hline OI- $33-45 E$ & & 75 & 18 & 6 & 1 & \\
\hline OI-18 & & & 16 & 60 & 24 & \multirow{4}{*}{ 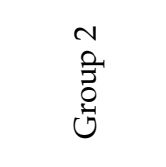 } \\
\hline OI-22-13E & & 5 & 11 & 57 & 27 & \\
\hline OI-22-18E & & 18 & 7 & 59 & 15 & \\
\hline OI-22-51E & & 20 & 9 & 56 & 15 & \\
\hline OI-19 & & 43 & \multirow{13}{*}{3} & 45 & 11 & \multirow{13}{*}{$\begin{array}{l}m \\
2 \\
0 \\
0 \\
0 \\
0\end{array}$} \\
\hline OI-20 & & 3 & & 70 & 27 & \\
\hline OI-21 & & & & 76 & 26 & \\
\hline OI-22-16E & & & & 87 & 13 & \\
\hline OI-22-23E & & 7 & & 93 & & \\
\hline OI-23-22E & & 17 & & 73 & 10 & \\
\hline OI-25-43E & & 7 & & 77 & 13 & \\
\hline OI-25-50E & & & & 83 & 14 & \\
\hline OI-26-1 & & & & 51 & 49 & \\
\hline OI-27 & & 20 & & 74 & 6 & \\
\hline OI-27-57E & & & & 81 & 19 & \\
\hline OI-28 & & 19 & & 38 & 43 & \\
\hline OI-31 & & 2 & & 84 & 14 & \\
\hline OI-II-02 & \multirow{10}{*}{ 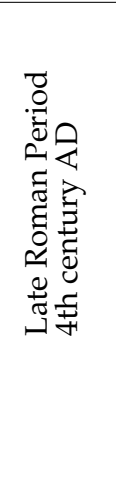 } & 20 & 10 & 54 & 15 & \multirow{9}{*}{ 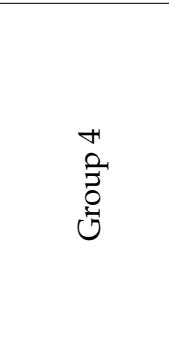 } \\
\hline OI-II-03 & & 6 & 26 & 68 & & \\
\hline OI-II-04 & & 19 & 21 & 60 & & \\
\hline OI-II-05 & & & 17 & 67 & 16 & \\
\hline OI-II-06 & & 21 & 13 & 52 & 14 & \\
\hline OI-II-07 & & 4 & 15 & 68 & 13 & \\
\hline OI-II-08 & & 5 & 28 & 67 & & \\
\hline OI-II-09 & & & 24 & 77 & & \\
\hline OI-II-10 & & & 11 & 70 & 19 & \\
\hline OI-II-12 & & 16 & 23 & 44 & 17 & 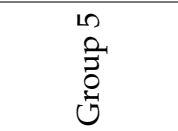 \\
\hline
\end{tabular}

SEM-EDS analyses allow the observation of microtextural features and supply details of the mineralogical assemblage of the slags. Skeletal and massive olivines appear in light-grey colors, while dendritic wuestite is white. Wuestite appears intergrown both inside and among the olivine crystals sometimes showing spiky fern-like dendritic growth. In Group 1 slags, scarce white crystals showing cruciform habit also observed intergrowing inside olivine correspond to magnetite crystals (Figure 4a). Most of the studied slags show skeletal olivine and dendritic wuestite regardless of the group whereas 
the spinifex textures and white skins are only present in Group 3 slags (Figure 4b,c). In slags with weak magnetism (Group 3) greyish color cruciform crystals were also observed but EDS analyses showed the presence of aluminum indicative of a mineral phase in the spinel group, corresponding to hercynite (Figure $4 \mathrm{~d}$ ). The occurrence of cruciform crystals is a result of rapid crystallization. High degree of undercooling leads to crystal shapes with the highest rate of growth yielding skeletal and dendritic crystals. In contrast, with a small degree of undercooling planar faces can develop leading to euhedral crystals similar to features in the massive olivines in the Medieval Group 1 and Roman Groups [37].
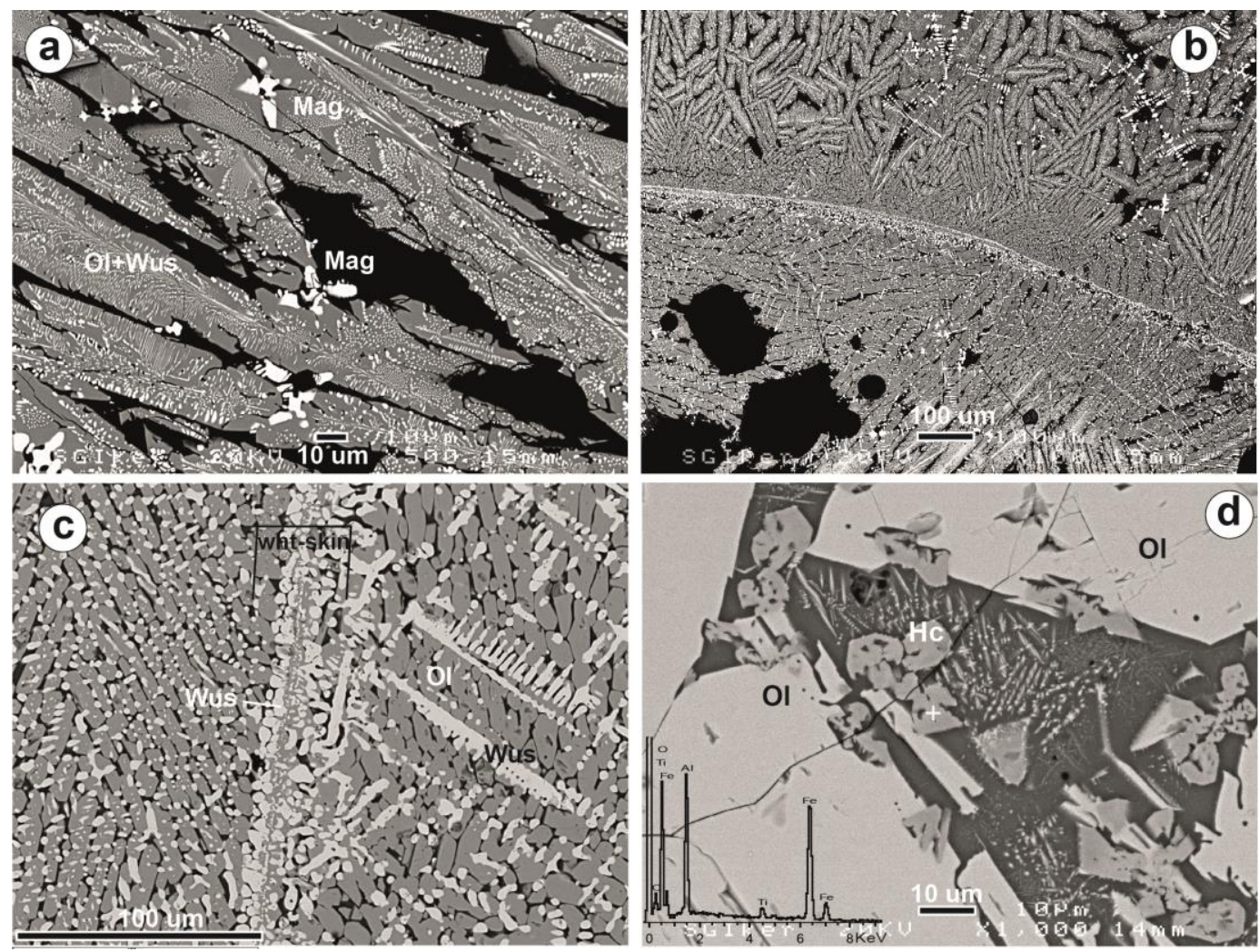

Figure 4. SEM-BSE images. (a) skeletal olivines (light-grey colors), dendritic wuestite and cruciform magnetite (white colors) in Group 1. (b) white skins and the spinifex olivines in Group 3. (c) detail of white skins. (d) polyhedral olivines (light-grey colors) and euhedral-cruciform hercynite (grey colors) and EDS spectra of hercynite taken at + spot on the image in Group 3. Abbreviations after [36]: Ol: Olivine, Wus: Wuestite, Mag: Magnetite, Wht-skin: white skin, Hc: Hercynite.

Olivine composition determined by EDS analysis corresponds to fayalite end member without any compositional variation regardless the slag group (Table 3). Besides, two intense Raman shifts in the region of 700 and $1100 \mathrm{~cm}^{-1}$ with a doublet dominant in $812 \mathrm{~cm}^{-1}$ and $837 \mathrm{~cm}^{-1}$, and below $400 \mathrm{~cm}^{-1}$ are attributed to Fe-rich olivine corresponding to fayalite member (Figure 5a) [38,39].

Furthermore, white lines observed by optical microscopy in Group 3 have been analyzed with SEM-EDS. At SEM above x500 magnification, the white lines observed in reflected light microscopy are composed by two parallel chains formed by droplet-shaped particles (Figure $4 b, c)$. These white lines have been attributed to magnetite skins [40]. However, EDS analyses were unable to specify the white skin composition. The brightness in the backscattered electrons (BSE) image is correlated with the atomic number of the phase. The droplet-shaped particles of the white skins are similar to dendritic wuestite, indicating the same chemical composition and suggesting the white skins will be composed mainly by wuestite. 
Table 3. SEM-EDS chemical composition of olivines in Roman and Medieval Age slag Groups

\begin{tabular}{|c|c|c|c|c|c|c|c|c|}
\hline & \multicolumn{2}{|c|}{$\begin{array}{c}\text { Group } 1 \\
\text { Medieval }\end{array}$} & \multicolumn{2}{|c|}{$\begin{array}{c}\text { Group } 2 \\
\text { Medieval }\end{array}$} & \multicolumn{2}{|c|}{$\begin{array}{l}\text { Group } 3 \\
\text { Medieval }\end{array}$} & \multicolumn{2}{|c|}{$\begin{array}{c}\text { Group } 4 \\
\text { Roman }\end{array}$} \\
\hline$n=$ & $\begin{array}{c}\text { average } \\
18\end{array}$ & SD & $\begin{array}{c}\text { average } \\
28\end{array}$ & SD & $\begin{array}{c}\text { average } \\
15\end{array}$ & SD & $\begin{array}{c}\text { average } \\
12\end{array}$ & SD \\
\hline $\begin{array}{l}\mathrm{SiO}_{2} \\
\mathrm{MgO}\end{array}$ & $\begin{array}{c}32.44 \\
0.58\end{array}$ & $\begin{array}{l}0.25 \\
0.08\end{array}$ & 32.64 & 0.72 & $\begin{array}{c}32.68 \\
0.76\end{array}$ & $\begin{array}{l}0.33 \\
0.29\end{array}$ & 34.64 & 0.16 \\
\hline $\mathrm{FeO}$ & 64.33 & 0.12 & 64.06 & 2.50 & 63.45 & 1.48 & 63.31 & 0.30 \\
\hline $\mathrm{CaO}$ & & & 1.25 & 0.87 & 0.48 & 0.17 & 0.39 & 0.13 \\
\hline $\mathrm{MnO}$ & 2.46 & 0.08 & 0.90 & 0.10 & 2.73 & 1.12 & 1.13 & 0.15 \\
\hline
\end{tabular}

Abbreviations: SD, standard deviation.

Raman spectroscopy was performed to characterize the mineralogy of white skins present in the slags in Group 3 (Figures 3d and $4 \mathrm{~b}$ ). Characteristic Raman shifts at $300 \mathrm{~cm}^{-1}, 544 \mathrm{~cm}^{-1}$ and $672 \mathrm{~cm}^{-1}$ can be attributed to magnetite [41] (Figure 5b). The identification of magnetite in the white lines is in accordance with the reported data in literature [35,40]. Nevertheless white skins are only present in slags with weak or absent magnetism, which is in direct conflict with the Raman results. Several studies report the degradation of some iron oxide due to the laser power used for Raman spectra [41-43]. Results show that, when increasing laser power and acquisition time, the characteristic wuestite band becomes narrower and undergoes a small shift with new bands attributed to magnetite appearing [41-43]. Considering these studies, the lack of magnetism and the SEM-EDS results, it cannot be affirmed that the white skins in Group 3 slags from Oiola IV are composed of magnetite.
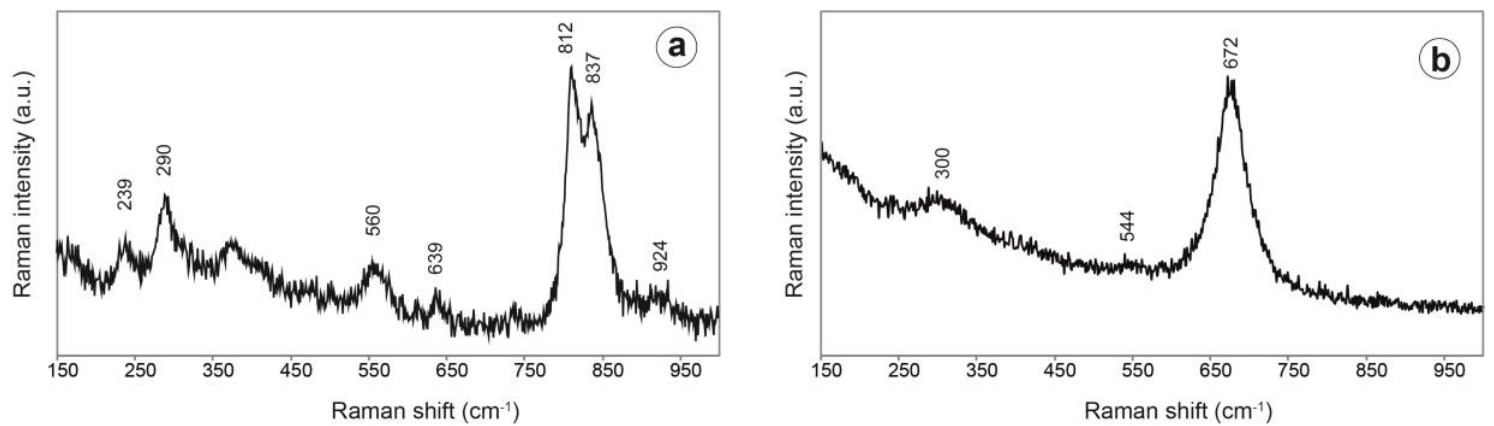

Figure 5. Raman spectra (a) Olivine spectrum. (b) White skins spectrum.

SEM-EDS analysis can also analyze the vitreous matrix of the slags since the microchemical composition of the matrix is used to determine the smelting process temperature. However, SEM observations show that in slags in Group 1 (Middle Ages) and Groups 4 and 5 (Roman period) the vitreous matrix is scarce and filled with olivine and hercynite microcrystals (Figure 6). Groups 2 and 3 show small areas apparently free of microcrystals.

The EDS microanalyses of the glassy phase are similar and reveal an aluminum iron silicate composition with minor amounts of calcium and potassium (Table 4). Plotting vitreous matrix chemical composition in diagrams $\mathrm{SiO}_{2}-\mathrm{CaO}-\mathrm{FeO}$ indicate theoretical melting temperatures from $1400{ }^{\circ} \mathrm{C}$ to $1700{ }^{\circ} \mathrm{C}$, which disagree with studies of bloomery iron smelting [35]. Considering the microvolume of the X-ray emission of SEM-EDS microanalysis spot (Figure 6) the microcrystals composition may be partially included in the vitreous phase composition modifying the chemical composition of the glass. Thus, the analytical results of the vitreous matrix may be questionable. 

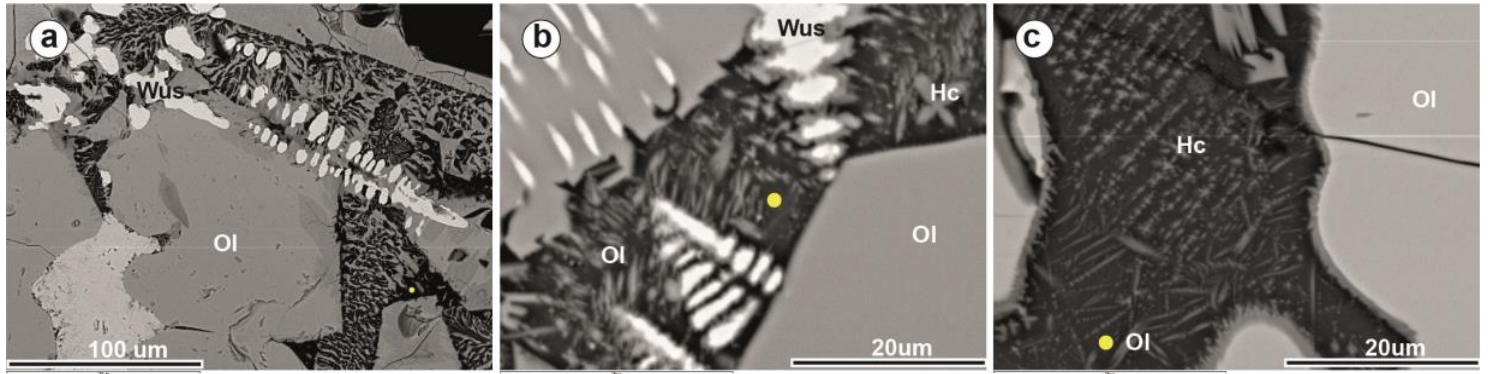

Figure 6. SEM-BSE images showing microcrystals in the vitreous matrix (a) Representative image of glass in Medieval Group 1. (b) Representative image of glass in Roman Group 4. (c) Representative image of glass in Medieval Group 3. Yellow circles correspond to $1 \mu \mathrm{m}$ representative of minimum EDS analytical spot. Abbreviations after [36]: Ol: Olivine, Wus: Wuestite, Hc: Hercynite.

Due to the doubtful chemical composition of the glassy matrix, temperature-dependent powder X-ray diffraction (TDX) was performed to estimate the pyrometallurgical conditions. Oiola ore sample was heated in a high temperature chamber in environmental conditions to observe phase transitions occurring at different temperatures. The ore sample consists of goethite and a minor amount of quartz. The phase transition from goethite to hematite can be observed during heating. In the TDX stacking patterns, goethite breakdown at $300^{\circ} \mathrm{C}$ can be observed by the absence reflection $21.26^{\circ} 2 \theta$ (Figure 7). Over $300^{\circ} \mathrm{C}$ new iron oxides are formed since new reflections appear corresponding to wuestite that, as temperature increases, transforms to hematite. This transformation can be observed both by the refection shift toward to position lower $2 \theta$ (Figure 7a) and by the increase in hematite reflections intensity mainly at $33.20^{\circ} 2 \theta, 49.48^{\circ} 2 \theta, 54.08^{\circ} 2 \theta$ (Figure $7 \mathrm{~b}$ ) [44]. At $870^{\circ} \mathrm{C}$ some reflections of quartz disappear and new reflections appear corresponding to trydimite. The absence of olivine can be related to the low amount of quartz in the ore.

Table 4. SEM-EDS chemical composition of glasses of Roman and Medieval Age slag groups

\begin{tabular}{ccccccccc}
\hline & \multicolumn{2}{c}{$\begin{array}{c}\text { Group 1 } \\
\text { Medieval }\end{array}$} & \multicolumn{2}{c}{$\begin{array}{c}\text { Group 2 } \\
\text { Medieval }\end{array}$} & \multicolumn{2}{c}{$\begin{array}{c}\text { Group 3 } \\
\text { Medieval }\end{array}$} & \multicolumn{2}{c}{$\begin{array}{c}\text { Group 4 } \\
\text { Roman }\end{array}$} \\
\hline & $\begin{array}{c}\text { average } \\
n=\end{array}$ & SD & $\begin{array}{c}\text { average } \\
24\end{array}$ & SD & average & SD & average & SD \\
& & 28 & & 56 & & 48 & \\
\hline $\mathrm{SiO}_{2}$ & 46.74 & 1.15 & 41.72 & 3.83 & 42.41 & 3.16 & 43.41 & 3.54 \\
$\mathrm{Al}_{2} \mathrm{O}_{3}$ & 13.32 & 0.70 & 18.30 & 1.41 & 20.65 & 2.16 & 18.33 & 1.59 \\
$\mathrm{TiO}_{2}$ & 1.61 & 0.16 & 0.56 & 0.12 & 0.37 & 0.06 & 0.53 & 0.04 \\
$\mathrm{FeO}$ & 17.26 & 0.16 & 22.06 & 7.76 & 20.99 & 6.96 & 20.89 & 2.68 \\
$\mathrm{CaO}$ & 15.21 & 0.43 & 11.04 & 2.54 & 7.83 & 2.76 & 8.94 & 2.38 \\
$\mathrm{Na}_{2} \mathrm{O}$ & 0.63 & 0.07 & 0.59 & 0.06 & 1.09 & 0.10 & 0.68 & 0.12 \\
$\mathrm{~K}_{2} \mathrm{O}$ & 0.86 & 0.03 & 5.20 & 0.50 & 6.69 & 0.62 & 5.05 & 1.93 \\
$\mathrm{P}_{2} \mathrm{O}_{5}$ & 2.33 & 0.26 & 0.63 & 0.09 & 0.64 & 0.10 & 0.63 & 0.07 \\
\hline
\end{tabular}

Abbreviations: SD, standard deviation. 
(a)
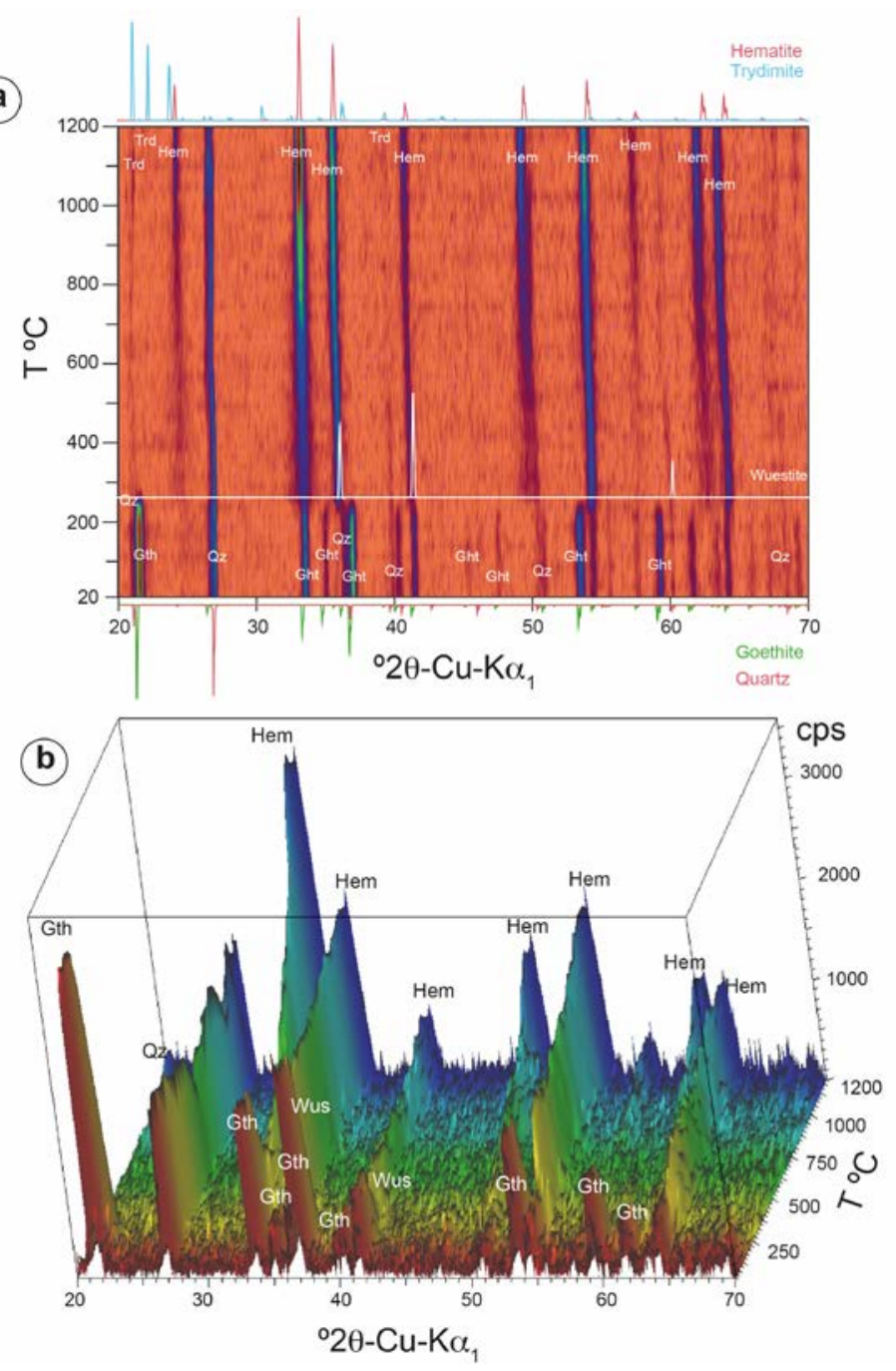

Figure 7. Thermodiffraction patterns for iron ore from Oiola heated between $30-1205^{\circ} \mathrm{C}$ and from 20 to $70^{\circ} 2 \theta$ range as stacked patterns showing phase transition at different temperatures. (a) stacking of 1D diffractograms; (b) stacking of 3D diffractograms. Abbreviations after [36]: Hem: Hematite, Qz: Quartz, Trd: Tydimite, Gth-Goethite: Wus: Wuestite.

The transition temperatures obtained in environmental conditions simulated by X-ray diffraction differ from measurements performed under reducing conditions. To characterize smelting conditions used in ancient ironmaking in Oiola, Thermo-Gravimetric Analysis (TGA) was carried out in both inert and environmental atmospheres with simultaneous recording of the loss of weight of the sample while temperature rises at a uniform rate. Nevertheless, the net weight loss and the kinetic parameters obtained are based on simplified assumptions which do not necessary correspond to the complex chemical reactions occurring during the transformation of iron ores into metal.

The results of thermal analysis of goethite ore powder are shown in Figure 7. Upon heating, the DSC/TG profiles in both inert and environmental atmospheres show an endothermic peak at around $300{ }^{\circ} \mathrm{C}$ with an associated weight loss of $10.7 \%$ due to the dehydroxylation of goethite (Figure $8 \mathrm{a}$ ). At this temperature the goethite $(\mathrm{FeOOH})$ transforms into hematite $\left(\mathrm{Fe}_{2} \mathrm{O}_{3}\right)$ as has been observed in the TDX analysis (Figure 7a). The relatively low weight loss (ca. $1.5 \%$ of weight) between $350{ }^{\circ} \mathrm{C}$ to 600 ${ }^{\circ} \mathrm{C}$ related to the decomposition of clays can be identified [45-47]. In the DSC curve of environmental conditions (Figure 8a) a second stage was identified between $650{ }^{\circ} \mathrm{C}$ and $960^{\circ} \mathrm{C}$ corresponding to the wuestite to hematite transformation in accordance with the TDX results [44]. The endothermic peak 
found at $1140{ }^{\circ} \mathrm{C}$ was attributed to the melting temperature. Conversely, in inert atmosphere the iron ore oxidation was not observed because oxygen was not available (Figure $8 \mathrm{~b}$ ). Thermogravimetric and heat curves for synthetic goethite ore powder mixed with quartz in a rate of 70/40 are also shown in Figure 8a (green curve). Addition of quartz as flux material decreases the temperatures of iron ore oxidation stages and the melting point decreases from about $1140{ }^{\circ} \mathrm{C}$ to about $890^{\circ} \mathrm{C}$. The addition of flux material decreases the melting temperature by around $250{ }^{\circ} \mathrm{C}$.
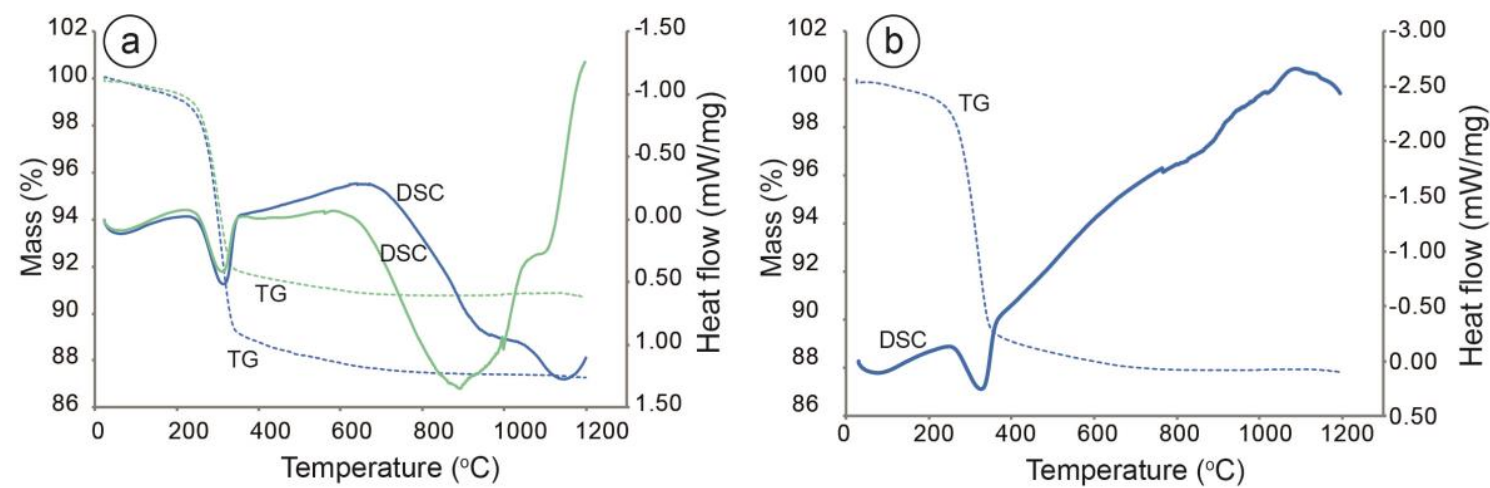

Figure 8. Thermogravimetric profiles of iron ore. (a) DSC/TG curves in environmental atmosphere of iron ore (in blue) and iron ore with quartz flux (in green). (b) DSC/TG curves in inert atmosphere.

Mineralogical and textural features of slags combined with temperature-dependent reactions can be used to explore pyrometallurgical conditions in ironmaking from the Roman Age to the Middle Ages. The morphology and crystal size distribution indicate different smelting temperatures. Skeletal and dendritic morphologies suggest temperature undercooling rates $\Delta \mathrm{T}>150{ }^{\circ} \mathrm{C}$ whereas massive morphologies suggest $\Delta \mathrm{T}<100{ }^{\circ} \mathrm{C}[37,48,49]$. Dendritic wuestite present in all slags is indicative of the fast cooling of tap-slags outside the furnace (Figures $3 \mathrm{c}$ and $5 \mathrm{a}$ ). Fast undercooling also resulted in skeletal olivines present in Groups 2 and 3 Medieval slags. Massive olivines in Group 1 slags and in the Roman slags indicate slower cooling rates (Figure 3a,b and Figure 5a,b). Besides spinifex textures observed in Group 3 slags indicate high undercooling rates $\Delta \mathrm{T}>20{ }^{\circ} \mathrm{C}$, showing that these cooled the fastest.

Mineral assemblage of slags allows the furnace operating conditions to be estimated. The presence of magnetite indicates oxidation during the iron smelting. Magnetite occurs in most slags except in Group 3 (Table 3). The air trapped in the porous system yielded the wuestite oxidation to magnetite. Nevertheless, Roman slags with low porosity suggest magnetite formation due to excessive air supply into the furnace, indicating a less efficient smelting process [50].

The presence of hercynite together with the aluminum content of the vitreous matrix indicates aluminum-bearing ore. Considering the local ore minerals, the occurrence of clays is related to the weathering of the country rock yielding the txirteras composed of goethite and quartz and a minor amount of clay minerals. The presence of clay minerals suggests whole iron bog ores including the ferric upper weathered horizon was used.

Dendritic wuestite and the assemblage of olivine and wuestite in smelting slags suggest furnace temperatures lower than $1200^{\circ} \mathrm{C}$, less than the melting temperature of iron $\left(1560^{\circ} \mathrm{C}\right)[7,50]$. The addition of fluxes like quartz allows the iron melting temperature to be decreased [50,51]. The results of TGA analyses with the addition of quartz as a flux show a melting temperature decrease from $1140{ }^{\circ} \mathrm{C}$ to $890^{\circ} \mathrm{C}$. The addition of quartz in iron ore smelting at Oiola is verified by the lack of olivine and wuestite in the TDX analyses since the quartz content in the bog ore is not enough to form olivine. 


\section{Conclusions}

The presence of bloomery smelting wastes found at the Oiola archaeological site indicates that iron mining in the mining complex of La Arboleda (Biscay) began at least to the Roman Period. Skeletal and dendritic morphological features of olivine and wuestite and spinifex textures suggest rapid cooling rates of the Medieval slags in Groups 2 and 3 whereas massive olivine present in Medieval Group 1 and Roman slags indicates lower cooling rates. The presence of magnetite indicates poor control of the air supply in the furnace due to a large oxygen supply, reflected by the variable porosity of slags.

Additionally, samples containing hercynite confirm the use of bog iron ore consisting mainly of goethite, quartz and a minor amount of clay minerals as the raw material used in the ironmaking.

Mineral assemblages also allow furnace temperature and operating conditions to be estimated. The addition of quartz as flux resulted in a melting temperature decrease of around $200^{\circ} \mathrm{C}$. Although the smelting conditions in the reduction furnace could not be replicated, TGA analysis in inert atmosphere is the most similar model. These results suggest that the temperature to reduce iron would be around 980-1000 ${ }^{\circ} \mathrm{C}$, using quartz as a flux.

The comparison of the mineralogical assemblage and textural features of smelting slags from the Late Roman Period and the Middle Ages suggests changes in the pyrometallurgical process towards more efficient processes.

Author Contributions: H.P.-B. selected the archaeological materials, performed the analysis and wrote the paper; J.J.C.-O. and A.M.S. executed the archaeological study, the sampling strategy and collected the samples; H.P.-B., M.C.Z., L.A.O. analyzed the data, wrote the paper and, contributed to the discussion; A.A.-O. contributed to the discussion. All authors contributed to discussion of results of this study. All authors have read and agreed to the published version of the manuscript.

Funding: This study was partially supported by the T1193-13 project of the Basque Country Government.

Acknowledgments: H.P.-B. would like to thank the PRE-2019-2-0138 PhD research grant of the Basque Country Government and the SGIker service at the University of the Basque Country. The authors thank anonymous reviewers for constructive comments and suggestions that improved the manuscript. The authors would also like to thank Peter Smith for language assistance.

Conflicts of Interest: The authors declare no conflict of interest regarding this manuscript.

\section{References}

1. Pleiner, R. Iron in Archaeology: The European Bloomery Smelters; Archeologický Ústav Avčr: Prague, Czech Republic, 2000.

2. Serneels, V.; Perret, S. Quantification of smithing activities based on the investigation of slag and other material remains. Archaeometall. Eur. 2003, 1, 469-478.

3. McDonnell, J.G. The Classification of Early Ironworking Slags. Ph.D. Thesis, University of Aston, Birmingham, UK, 1986.

4. Selskienè, A. Examination of smelting and smithing slags formed in bloomery iron-making process. Chemija 2007, 18, 22-28.

5. Senn, M.; Gfeller, U.; Guénette-Beck, B.; Lienemann, P.; Ulrich, A. Tools to qualify experiments with bloomery furnaces. Archaeometry 2010, 52, 131-145. [CrossRef]

6. Charlton, M.F.; Blakelock, E.; Martinón-Torres, M.; Young, T. Investigating the production provenance of iron artifacts with multivariate methods. J. Archaeol. Sci. 2012, 39, 2280-2293. [CrossRef]

7. Charlton, M.F.; Crew, P.; Rehren, T.; Shennan, S.J. Explaining the evolution of ironmaking recipes-An example from northwest Wales. J. Anthropol. Archaeol. 2010, 29, 352-367. [CrossRef]

8. Parreño, C.M.; Martín, A.M.; Ferrer Eres, M.Á. Iron, Fuel and Slags: Reconstructing the Ironworking Process in Iberian Iron Age (Valencian Region). Pyrenae 2009, 40, 105-127.

9. Tylecote, R.F. Furnaces, Crucibles and Slags, in the Coming of the Age of Iron; Wertime, T.A., Muhly, J.D., Eds.; Yale University Press: New Haven, CT, USA, 1980; pp. 183-226.

10. Buchwald, V.F.; Wivel, H. Slag analysis as a method for the characterization and provenancing of ancient iron objects. Mater. Charact. 1998, 40, 73-96. [CrossRef] 
11. Bayley, J.; Dughworth, D.; Paynter, S. Centre for Archaeology Guidelines: Archaeometallurgy; English Heritage: London, UK, 2001.

12. Ros-Latienda, L.; Fernández Carrasquilla, J. Caracterización de escorias metalúrgicas procedentes de yacimientos arqueológicos de Navarra (siglos II a.C.-IV d.C.). Rev. Metal. 2013, 49. [CrossRef]

13. Eekelers, K.; Degryse, P.; Muchez, P. Petrographic investigation of smithing slag of the Hellenistic to Byzantine city of Sagalassos (SW-Turkey). Am. Mineral. 2016, 101, 1072-1083. [CrossRef]

14. Blakelock, E.; Martinon-Torres, M.; Veldhuijzen, H.A.; Young, T. Slag inclusions in iron objects and the quest for provenance: An experiment and a case study. J. Archaeol. Sci. 2009, 36, 1745-1757. [CrossRef]

15. Cleere, H. Some operating parameters for Roman ironworks. Bull. Inst. Archaeol. 1976, 13, 233-246.

16. Crew, P. The influence of clay and charcoal ash on bloomery slags. In Il Ferro nelle Alpi, Giacimenti Miniere e Metallurgia dall'Antichità al XVI Secolo, Atti del Convegno, Proceedings of The Conference, Bienno, Italy, 2-4 Ottobre 1998; Comune di Bienno: Bienno, Italy, 2000; pp. 38-48.

17. Paynter, S. Regional variations in bloomery smelting slag of the Iron Age and Romano-British periods. Archaeometry 2006, 48, 271-292. [CrossRef]

18. Gordon, R.B. Process deduced from ironmaking wastes and artefacts. J. Archaeol. Sci. 1997, $24,9-18$. [CrossRef]

19. Benvenuti, M.; Mascaro, I.; Costagliola, P.; Tanelli, G.; Romualdi, A. Iron, copper and tin at Baratti, Populonia: Smelting processes and metal provenances. His. Metal. 2000, 34, 67-76.

20. Török, B.; Gallina, Z.; Kovacs, A.; Kristaly, F. Early medieval iron bloomery centre at Zamárdi (Hungary) Complex archaeometrical examinations of the slags. Archeologické Rozhledy 2018, 70, 404-420.

21. Tylecote, R.F.; Austin, J.N.; Wraith, A.B. The mechanism of the bloomery process in shaft furnaces. J. Iron Steel Inst. 1971, 209, 342-363.

22. Pereda García, I. La metalurgia prehidráulica del hierro en Bizkaia: El caso de los alrededores del pantano de Oiola (Trapagarán, Bizkaia). Kobie 1992, 20, 109-122.

23. Gil-Crespo, P.P. Introducción a la geología y mineralogía de los yacimientos de hierro de Bilbao. In Historia del Hierro en Bizkaia y su Entorno; Orue-Etxebarria, X., Apellaniz, E., Gil-Crespo, P.P., Eds.; Real Sociendad Bascongada de los Amigos del País: Bilbao, Spain, 2015; pp. 19-52.

24. Kaczorek, D.; Sommer, M. Micromorphology, chemistry, and mineralogy of bog iron ores from Poland. Catena 2003, 54, 393-402. [CrossRef]

25. Kaczorek, D.; Sommer, M.; Andruschkewitsch, I.; Oktaba, L.; Czerwinski, Z.; Stahr, K. A comparative micromorphological and chemical study of "Raseneisenstein" (bog iron ore) and "Ortstein". Geoderma 2004, 121, 83-94. [CrossRef]

26. Banning, A. Bog iron ores and their potential role in arsenic dynamics: An overview and a "Paleo Example". Eng. Life Sci. 2008, 8, 641-649. [CrossRef]

27. Thelemann, H.; Bebermeier, W.; Hoelzmann, P.; Lehnhardt, E. Bog iron ore as a resource for prehistoric iron production in Central Europe-A case study of the Widawa catchment area in eastern Silesia, Poland. Catena 2017, 149, 474-490. [CrossRef]

28. Kaczorek, D.; Brümmer, G.; Sommer, M. Content and binding forms of heavy metals. Aluminium and phosphorus in bog iron ores from Poland. J. Environ. Qual. 2005, 38, 1109-1119. [CrossRef] [PubMed]

29. García-Mondéjar, J.; Fernández-Mendiola, P.A.; Agirrezabala, L.M.; Aranburu, A.; López-Horgue, M.A.; Iriarte, E.; Martínez de Rituerto, S. El Aptiense-Albiense de la Cuenca Vasco-Cantábrica. In Geología de España; Vera, J.A., Ed.; SGE-IGME: Madrid, Spain, 2004; pp. 291-296.

30. Gil Crespo, P.P. Las Mineralizaciones de Hierro en el Anticlinal de Bilbao: Mineralogía, Geoquímica y Metalogenia. Ph.D. Thesis, University of the Basque Country, Leioa, Spain, 1991.

31. Portillo, H.; Zuluaga, M.C.; Ortega, L.A.; Alonso-Olazabal, A.; Murelaga, X.; Martinez-Salcedo, A. XRD, SEM/EDX and micro-Raman spectroscopy for mineralogical and chemical characterization of iron slags from the Roman archaeological site of Forua (Biscay, North Spain). Microchem. J. 2018, 138, 246-254. [CrossRef]

32. Beukes, N.J.; Gutzmer, J.; Mukhopadhyay, J. The geology and genesis of high-grade hematite iron ore deposits. Appl. Earth Sci. 2003, 112, 18-25. [CrossRef]

33. Ixer, R.A. Atlas of Opaque and Ore Minerals in Their Associations; Osprey Books: Oxford, UK, 1990.

34. Ramdohr, P. The Ore Minerals and Their Intergrowths; Elsevier: Amsterdam, The Netherlands, 2013. 
35. Park, J.S.; Rehren, T. Large-scale 2nd to 3rd century AD bloomery iron smelting in Korea. J. Archaeol. Sci. 2011, 38, 1180-1190. [CrossRef]

36. Whitney, D.L.; Evans, B.W. Abbreviations for names of rock-forming minerals. Am. Mineral. 2010, 95, 185-187. [CrossRef]

37. Vernon, R.H. A Practical Guide to Rack Microstructure; Cambridge University Press: Cambridge, UK, 2004.

38. Kolesov, B.A.; Geiger, C.A. A Raman spectroscopic study of Fe-Mg olivines. Phys. Chem. Miner. 2004, 31, 142-154. [CrossRef]

39. Mouri, T.; Enami, M. Raman spectroscopic study of olivine-group minerals. J. Miner. Petrol. Sci. 2008, 103, 100-104. [CrossRef]

40. Ackerman, K.J.; Killick, D.J.; Herbert, E.W.; Kriger, C. A study of iron smelting at Lopanzo, Equateur Province, Zaire. J. Archaeol. Sci. 1999, 26, 1135-1143. [CrossRef]

41. De Faria, D.L.A.; Venâncio Silva, S.; De Oliveira, M.T. Raman microspectroscopy of some iron oxides and oxyhydroxides. J. Raman Spectrosc. 1997, 28, 873-878. [CrossRef]

42. Hanesch, M. Raman spectroscopy of iron oxides and (oxy)hydroxides at low laser power and possible applications in environmental magnetic studies. Geophys. J. Int. 2009, 177, 941-948. [CrossRef]

43. Shebanova, O.; Lazor, P. Raman study of magnetite (Fe3O4): Laser-induced thermal effects and oxidation. J. Raman Spectrosc. 2003, 34, 845-852. [CrossRef]

44. Jozwiak, W.K.; Kaczmarek, E.; Maniecki, T.P.; Ignaczak, W.; Maniukiewicz, W. Reduction behavior of iron oxides in hydrogen and carbon monoxide atmospheres. Appl. Catal. A Gen. 2007, 326, 17-27. [CrossRef]

45. Strezov, V.; Ziolkowski, A.; Evans, T.; Nelson, P. Assessment of evolution of loss on ignition matter during heating of iron ores. J. Therm. Anal. Calorim. 2009, 100, 901-907. [CrossRef]

46. Kawigraha, A.; Soedarsono, J.W.; Harjanto, S. Thermogravimetric Analysis of the Reduction of Iron Ore with Hydroxyl Content. J. Adv. Mater. Res. 2013, 774, 682-686. [CrossRef]

47. Romero Gómez, P.; González, J.C.; Bustamante, A.; Ruiz Conde, A.; Sánchez Soto, P.J. Estudio in-situ de la transformación térmica de limonita utilizada como pigmento procedente de Perú. Bol. Soc. Esp. Cerám. Vidr. 2013, 52, 127-131. [CrossRef]

48. Castro-Dorado, A. Petrografía de Rocas Ígneas y Metamórfica; Paraninfo: Madrid, Spain, 2015.

49. Donaldson, C.H. An experimental investigation of olivine morphology. Contrib. Miner. Petr. 1976, 57, 187-213. [CrossRef]

50. Manasse, A.; Mellini, M. Chemical and textural characterisation of medieval slags from the Massa Marittima smelting sites (Tuscany, Italy). J. Cult. Herit. 2002, 3, 187-198. [CrossRef]

51. Gómez Ramos, P. Análisis de escorias férreas: Nuevas aportaciones al conocimiento de la siderurgia prerromana en España. Trab. Prehist. 1996, 53, 145-155. [CrossRef] 